\title{
Mapping the Landscape of Future Research Themes in Supply Chain Management
}

\author{
Wieland, Andreas; Handfield, Robert; Durach, Christian F.
}

\author{
Document Version \\ Accepted author manuscript \\ Published in: \\ Journal of Business Logistics
}

DOI:

$10.1111 / \mathrm{jbl} .12131$

Publication date:

2016

License

Unspecified

Citation for published version (APA):

Wieland, A., Handfield, R., \& Durach, C. F. (2016). Mapping the Landscape of Future Research Themes in Supply Chain Management. Journal of Business Logistics, 37(3), 205-212. https://doi.org/10.1111/jbl.12131

Link to publication in CBS Research Portal

\section{General rights}

Copyright and moral rights for the publications made accessible in the public portal are retained by the authors and/or other copyright owners and it is a condition of accessing publications that users recognise and abide by the legal requirements associated with these rights.

\section{Take down policy}

If you believe that this document breaches copyright please contact us (research.lib@cbs.dk) providing details, and we will remove access to the work immediately and investigate your claim.

Download date: 26. Apr. 2023

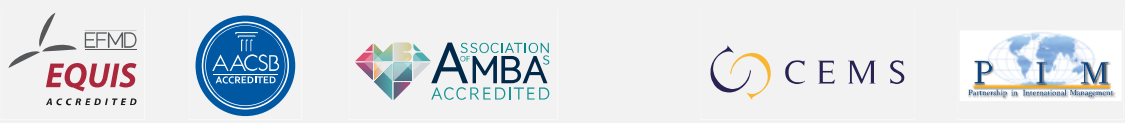




\section{Mapping the Landscape of Future Research Themes in Supply Chain Management}

\section{Andreas Wieland, Robert Handfield, and Christian F. Durach}

Journal article (Post print version)

This is the peer reviewed version of the following article:

Mapping the Landscape of Future Research Themes in Supply Chain Management. / Wieland, Andreas; Handfield, Robert; Durach, Christian F. I: Journal of Business Logistics, 04.08.2016, which has been published in final form at http://dx.doi.org/10.1111/jbl.12131

This article may be used for non-commercial purposes in accordance with Wiley Terms and Conditions for Self-Archiving.

Uploaded to Research@CBS: September २०16 


\title{
Mapping the Landscape of Future Research Themes in Supply Chain Management
}

\author{
Andreas Wieland, Robert Handfield, Christian F. Durach \\ To cite this manuscript: \\ Wieland, A., Handfield, R., Durach, C.F. 2016. \\ Mapping the Landscape of Future Research Themes in Supply Chain Management. \\ Journal of Business Logistics. Vol. 37, No. 3, pp. 1-8
}

\begin{abstract}
Supply chain researchers are confronted with a dizzying array of research questions, many of which are not mutually independent. This research was motivated by the need to map the landscape of research themes, identify potential overlapping areas and interactions, and provide guidelines on areas of focus for researchers to pursue. We conducted a three-phase research study, beginning with an open-ended collection of opinions on research themes collected from 102 SCM researchers, followed by an evaluation of a consolidated list of themes by 141 SCM researchers. These results were then reviewed by 10 SCM scholars. Potential interactions and areas of overlap were identified, classified, and integrated into a compelling set of ideas for future research in the field of SCM. We believe these ideas provide a forward-looking view on those themes that will become important, as well as those that researchers believe should be focused on. While areas of research deemed to become most important include big data and analytics, the most under-researched areas include efforts that target the "people dimension" of SCM, ethical issues and internal integration. The themes are discussed in the context of current developments that the authors believe will provide a valuable foundation for future research.
\end{abstract}

Keywords: Survey, Research Themes, Research Trends, Supply Chain Management

\section{INTRODUCTION}

Supply chain management (SCM) is often noted by scholars as one of the most rapidly changing management fields. Researchers have noted the plethora of predictions and forecasts related to significant technological and managerial changes that accompany 
the discipline's development (including Melnyk et al. 2009; Sanders et al. 2013; Economist Intelligence Unit 2013; Handfield et al. 2013; The Global Supply Chain Institute 2013; Kersten et al. 2014). While many studies predict rapid change in the world of supply chains, only a handful have sought to note how academics are responding, as well as projecting how they should respond to these rapid changes (e.g. Kouvelis et al. 2006; Stank et al. 2011; Vallet-Bellmunt et al. 2011). Given the lag effect and the lack of recent updates to many of the shifts in the global supply chain ecosystem, the time is ripe for an exploration of how the momentous changes in the global economic environment of the last four years will be reflected in the tenor of future academic research. In recent years, supply chain managers have experienced a major global recession, a rapid expansion of global footprints into emerging countries, suffered major disruptions, and have been called on to produce major improvements in sustainability, cost savings, and regulatory compliance (Handfield et al. 2013). An updated review of academic research directions in SCM is not only timely, but indeed warranted.

Research that seeks to identify future research themes has typically relied on literature reviews. However, looking backwards to predict the future (i.e., using literature reviews as an extrapolation method), provides limited insights into the trajectory of research in a field. We believe soliciting researchers' judgments (Meyer and Booker 1991) can lead to more insightful outcomes, as this approach maps out not only what thought leaders believe will become important, but also identifies areas where they believe insufficient work has occurred and more focused work is needed. Reporting on the data collected from 141 SCM researchers, this research seeks to address the following questions: (1) What are the future dominant research themes in SCM? (2) What are the most fruitful research areas when linking these different themes?

In order to provide an adequate answer to these questions, we employed a research approach that consisted of a two-phase survey and an additional explorative in-depth analysis (phase three). In the survey, we collected opinion polls on whether researchers distinguished between the themes they believe will become important versus the themes they think should become important. This approach led to initial insights as to whether the SCM research boat is sailing in the right direction. We "drilled down" into the should-become-important themes and sought to explore the potential overlaps and interactions between these themes, thereby identifying a secondary set of research areas that combine important research themes in a new way.

The resulting set of insights provides a compelling set of guidelines for future editors, researchers, Ph.D. advisors and their students to consider as they map the trajectory of their individual research agendas for the next decade. Our findings provide young researchers important insights into the future direction of our discipline, while also serving to guide well-published researchers with the opportunity to reflect on their 
current and future contributions to the field as recognized by their peers. Reflection at the right time has been shown to be one of the most critical components of learning (Di Stefano et al. 2015). Pausing to reflect on one's own accumulated knowledge may lead to greater learning than the accumulation of additional knowledge. Finally, our research points to the need for a more holistic view of supply chain themes, as our analysis points to the strong linkages that exist among these core research questions.

\section{METHODOLOGY}

\section{Survey sample selection}

Emerging research themes were identified based on data collected from informed researchers selected from within the SCM field through our 2013/2014 SCM Research Survey. To identify the sample of potential researcher respondents, we first selected four leading journals related to SCM, representing both the methodological and theoretical breadth of the discipline: Journal of Business Logistics, Journal of Operations Management, Journal of Supply Chain Management, and Production and Operations Management. In a second step, a list containing all authors having published in these journals between January, 2010 and September, 2013 was compiled. After deleting duplicate entries the final list contained 1,075 entries.

\section{Phase 1 of data collection: Identifying a set of themes}

The survey process consisted of two phases of data collection. In the first phase (November/December 2013), the targeted sample researchers were asked in an open question format to name up to three emerging themes that will be the subject of SCM research in the next five years. A total of 102 researchers responded to this question in the first phase of data collection, yielding 254 identifiable themes.

\section{Phase 2 of data collection: Evaluating the importance of themes}

A consolidated list of these themes was presented to the participants in the second phase of data collection (April/June 2014). This list contained all themes that were mentioned more than three times in the first phase of data collection, yielding a total of 24 themes. Synonymous terms were grouped together based on logical deduction (e.g. "behavior issues" and "behavioral SCM"), whereas themes that were simply related were kept as separate entries (e.g. “risk” and “resilience”). This grouping was independently conducted by three SCM researchers. An additional quality check was conducted for themes that were mentioned less than three times (a total of 58 themes). For each of these 58 themes, six SCM researchers were asked to evaluate on a 5-point Likert scale whether they think the theme was likely to become an important research direction $(1=$ do not agree at all; $5=$ totally agree). If the average agreement value was greater than 3.5, the theme was kept in the questionnaire. This yielded an additional 11 items. The 1,075 SCM sampled researchers were asked to evaluate if a theme will become an emerging theme, and if it should become an emerging SCM theme. For both questions a 
7-point Likert scale ( $1=$ do not agree at all; $7=$ totally agree) was used. The order of the themes was individually randomized to reduce any bias. A larger number of responses occurred in the second phase of data collection (141). The findings of our research are based on the analysis of 141 survey responses in the second phase of the survey.

\section{Phase 3 of data collection: Linking the most important themes}

Following this analysis, an additional in-depth analysis was conducted (July/August 2015). In this phase a data collection table - an empty version of Table 2 - was prepared, with 6 clusters of the 10 highest ranked should-become-important themes on each axis. Clustering of topics was carried out by grouping closely related themes. In specific, "sustainability”/“environmental issues”, "risk management”/“disruption” and "people dimension of SCM"/“behavioral issues" were grouped together. The table was sent to 13 SCM researchers. These researchers were selected based on (1) the significance of their research publication record and (2) the overlap between their research fields and the themes identified in the survey. Moreover, we sought out a core group of researchers whose publication record focused on at least one or more of the themes, and to also ensure that each theme had coverage by at least two researchers. All selected researchers had publications in one of the four journals or other leading journals that are related to the six themes. They were asked to complete a detailed response in answering a single question for each cell of the table: "What are the future research potentials when linking these two themes in SCM research?” Ten researchers returned the completed table within the allotted scheduled time.

\section{POTENTIALLY UNDER- AND OVERESTIMATED RESEARCH THEMES}

From the data, we first calculated the difference between the should-become-important score and the will-become-important score for each theme. In some cases there are interesting gaps between what the surveyed researchers believe will become an important theme and what they believe should become an important theme. (The latter category essentially represents a latent but unmet need in the literature.) We assume that it is possible to classify themes as either "in need of greater study by researchers", or alternatively, "not worthy of the attention they've received", based on their relevance to supply chain ecosystem dynamics. We first briefly discuss some research themes that respondents believe need more attention, followed by research themes that seem to get more research attention than they deserve. These results are summarized in Table 1. A positive difference score indicates that the should-become-important score is larger than the will-become-important score and the theme is thus expected to be underestimated in future SCM research projects; a negative difference score indicates that a theme is potentially overestimated. 
Table 1: Scholars’ perceptions of underestimated and overestimated emerging research themes in the next five years.

++++ INCLUDE TABLE ABOUT HERE ++++

- The "people dimension of SCM": Only a few studies explore the behavioral dynamics of consumers, managers or other individual actors within a supply chain system. It seems like too often research in our field is conducted on the (inter)organizational level of analysis; processes and relationships on the (inter)individual level are often neglected or assumed away. Feedback from participants notes that supply chains are not "soulless machines", but complex sociotechnical systems involving cognitive elements and impacted by face-to-face negotiations and conversations. For example, recent research demonstrates that human agents and governance-influencing properties of supply chain systems mutually influence each other over time (Tangpong et al. 2014). Such observations call for SCM researchers to devote greater effort on exploring the roles of individual actors and groups in decision-making models as well as conducting multi-method research that, for example, includes behavioral biases and influences on outcomes.

- Ethical issues along the supply chain: Recent disasters in the Bangladeshi fashion industry (Wieland and Handfield 2013), the European horsemeat scandal (Lawrence 2013), and revelations of cruelty across angora fur supply chains (PETA 2014) have given rise to discussions on the importance of ethical sourcing in the supply chain. One of these areas of interest is a predictive model for better understanding what drives labor unrest in major offshore supply chain parties. Potential events may include wage levels in a region relative to the price of food and housing, raw material supply etc. Under certain conditions, based on common thinking, many of today's low cost country supply chains are ripe for labor issues and disruptions.

- Internal integration between departments: In reviewing latent dimensions of supply chain integration considered in previous research projects, it became apparent that many conceptualizations of integration are incomplete, "leaving out the important central link of internal integration” (Flynn et al. 2010, p. 58). This is a surprising observation, particularly in light of the fact that prior research demonstrates external and internal integration practices have a synergistic effect on performance if they are jointly used (Droge et al. 2004). Indeed, respondents to our survey indicated that internal integration between different departments of an organization turns out to be a neglected theme. Do we put too much emphasis on the external rather than internal supply chains?

- Big data and analytics: Conversely, big data and analytics are assumed to be among the dominating research themes in the next years, but the answers to the question of whether these themes should get more attention was a bit less 
enthusiastic. These two themes were the only two themes with substantially negative differences between desired and expected importance values, suggesting that there has been perhaps too much "hype” around these issues. As we will discuss later, analytical approaches are certainly important in SCM, but researchers need to distinguish between the real potential, the "value", and the social media marketing of these themes created by consultants, software developers, and infrastructure providers. Managers should re-examine the temptation to call everything "big data" that is somehow related to any type of data analytics. Further, the ability to manipulate large data sets to create unique insights is also limited. Many companies seem to find themselves in the state of "big data, but small math".

\section{RECOMBINING IMPORTANT THEMES: RECOGNIZING FUTURE RESEARCH POTENTIALS}

Next, we identified suggestions made by 10 active SCM researchers (6 professors [including two former and one current editors of leading SCM journals], 1 associate professor, 3 assistant professors; located in the U.S. [4], Germany [2], Ireland [2], Denmark [1] and the UK [1]). Their input suggested a set of compelling interactions that exist after reviewing the should-become-important themes when they are linked to each other. Table 2 depicts an overview of some of the areas with the greatest potential for "interesting" research. A number of these highlighted areas are now further discussed.

Table 2: Some future research potentials when recombining the research themes.

$$
\text { ++++ INCLUDE TABLE ABOUT HERE ++++ }
$$

- Accepting that SCM decisions are inherently imperfect: Traditional supply chain models have often simply transferred management practices from the system “organization” to the system "supply chain”. However, given the globalized, multicultural and interlinked nature of supply chains - as Amaral and Tsay (2009) put it: "Real-world supply chains are messy" - a supply chain is usually much more complex than a company. Cognitive human capacity limitations are often the biggest boundary to overcome in supply chain decision-making frames. In the human decision-making context, traditional management approaches tend to fail. In other words, the supply chain context cannot assume that an objective and rational decision maker has transparent access to all the information required to operate a network. Rather than trying to optimize each link in the system, SCM needs to be more robust in assuming irrational agents, missing visibility and complex decisionmaking. For example, rather than trying to identify all possible risk sources along 
the end-to-end supply chain, managing supply chain risk should focus on building resilient product and supply chain designs to cope with multiple unexpected and non-transparent sources of disruption (Pettit et al. 2010).

- Redesigning supply chains to manage risk and improve sustainability: One way to cope with this new reality is by redesigning supply chains. The structure of a supply chain can have a huge impact on how vulnerable it is. In particular, by eliminating complexity from a supply chain, managers may also be able to reduce waste, emissions and risk (Bode and Wagner 2015; Durach et al. 2015). Analysis might reveal a possible link between the complexity of a supply chain and the frequency of disruptions that occur. Recent research has already highlighted that supply chains need to be redesigned by creating more resilience across the entire system rather than managing various risks at a local level. It is also possible that some forms of complexity (e.g., certain types of redundancy) could also reduce disruptions. SCM research needs to consider the appropriate design that facilitates value creation and reduces the likelihood of disruption under differing network ecosystems.

- Making sense of the "sea of data" along the supply chain: With the emergence of data science, predictive analytics and big data (Waller and Fawcett 2013), supply chain managers are increasingly being empowered to interpret data collected through the "Internet of Things". By integrating data from all parts of the supply chain and presenting them on a smart phone, dashboards will enable consumers to have more knowledge about the entire system and guide them in making more holistic and sustainable buying decisions. Also, managers can employ visual data graphics to better interpret important and less important signals, and to use new metrics to measure risk, sustainability and total cost. In general, the promise of data to generate new insights on the supply chain and to reduce complexity is exciting, but is still very much a misunderstood area. More data has not always equated to more information that aids decision-makers. It is up to researchers to explore how analytical frameworks can bring us closer to the dream of real end-to-end supply chain integration. In any case, supply chain management has finally reached the stage of end-to-end thinking beyond the first tier.

- Improving decision support tools in SCM: An important element of this new supply chain world could be the creation of improved decision support tools that make integrated supply chain data available for decision making. Although we need to understand that irrationality cannot be eliminated entirely, such tools can help to make decisions at least more objective. In this manner, rational decision making can be supported to better interpret information from other supply chain members, to better adjust objectives of supply chain members and to understand how organizational decisions could affect the entire supply chain system. This includes forecasting, early-warning and real-time applications (e.g., identifying disruptions 
before they occur based on social media data). Recent events suggest that supply chain managers of the future will increasingly become "analytical decision makers" rather than "hands-on optimizers".

- Dealing with resistance to supply chain innovations: Introducing new systems, processes, organizational structures, organizational cultures or regulatory standards may already be a difficult task to deploy within a single department or company due to social and cultural traditions. Organizational resistance becomes even much more challenging to manage in a supply chain that crosses organizational boundaries. In theory, it may make sense to introduce an innovative decision support platform that integrates data from multiple tiers and organizations in the supply chain. But how can suppliers and retailers be convinced to share their confidential data? The touchy subject of intellectual property and confidential concerns are often "assumed away" by researchers seeking to optimize multi-echelon networks. New research is needed to drill down into interpersonal and trust-related issues that are underlying interorganizational integration efforts.

\section{CONCLUSIONS}

Our discipline is facing a series of changes. In a volatile fast paced ecosystem in which disruptive events are the norm, familiar supply chain tenets are rapidly being challenged. Several recent developments suggest that a new "era” of supply chain challenges is upon us:

- Rising geopolitical tensions, higher labor costs in traditional low-costs countries and the emergence of innovative technologies such as 3D printing and improved robotics may soon create production supply chains that will be located closer to sales markets, for example in Europe and North America.

- The "smile of value creation" (Mudambi 2008) is further moving towards the "end points" of the supply chain. The implication is that companies are focused in two extremities of the value chain: (1) controlling customer data and (2) focusing on $\mathrm{R} \& \mathrm{D}$ and product innovation. The implication is that manufacturing and even engineering processes are outsourced to third parties, with a relative shift in emphasis on sourcing, product engineering, and marketing analytics.

- The movement towards driverless vehicles and new types of partnerships in the automotive industry suggests that vehicles may soon be offered by data-driven technology companies from Silicon Valley, not traditional engineering-focused organizations from Detroit, Germany or Japan.

- The Paris Declaration contains ambitious sustainability goals that will lead to entirely new business models and, eventually, supply chain models. The Rana Plaza building collapse has already changed the way the apparel industry deals with social responsibility and it seems that this new mindset is spreading to other industries. 
In all of these developments, SCM plays a key role - maybe even a more crucial role than in the past. The rapid changes in the global operating ecosystem offer fascinating opportunities for SCM researchers to immerse themselves in problems that are completely new, many of which can be linked to solid research approaches that can not only supplement these new operating models, but will also require researchers to set aside conventional thinking.

Our work in this research has singled out many new important themes in SCM. These identified research themes emphasize that the issues of sustainability, risk, humans, innovation, analytics and complexity cannot be studied in a void. Rather, these themes require strong interdisciplinary thought and rigorous approaches to consideration of these factors on supply chain outcomes. Further, our proposed list of high potential research themes provides a number of benefits for readers of this journal. Editors of leading SCM journals can benefit from the results of this study by allowing papers that fall in the group of underestimated research themes to receive priority in publication queues (Table 1). The themes may also be suitable for special issues dedicated to indepth research in these themes identified in the cross table of should-become-important themes (Table 2). Academics may also wish to hold special sessions at future professional meetings dedicated to the discussion and exploration of themes in these areas.

The identified research themes and their assessment of whether they are over- or underestimated should also provide insights to well-informed researchers. The findings of this study can be used by researchers to reflect on their own research trajectories. If researchers find their own intended research stream is validated by our findings, this may serve to further validate their intended efforts in this direction. If researchers observe that a gap exists between their intended direction and those identified as important in our research, there may be a need for evaluation of the research agenda, which may cause some to modify or re-direct the course of their individual research agendas. It may not be comfortable to shift research themes in mid-stream, but we encourage readers to not limit themselves to problems that are already well-studied, and to jump into the void of new problems with little developed theoretical bases.

Like any research initiative, our results are not without limitations. We acknowledge that the sample taps into researchers who have published in some of the most visible journals. We have, however, omitted other journals in our field, such as the International Journal of Physical Distribution \& Logistics Management, Journal of Purchasing \& Supply Management, or Supply Chain Management: An International Journal. We also did not include researchers who are on the cusp of new discoveries or doctoral dissertations that have not yet been published and are entirely new. The omission of these outlets and the possible omission of some important insights from other researchers are mentioned here as a possible limitation to this study. 
We also note that in spite of substantial differences between the answers to questions on themes that should be and that will be important, the largest of these differences was 0.69. All of these themes were clearly evaluated as important on both scales. As part of this forward-thinking article, our results should be perceived as directional in nature. In particular, we do not believe that big data and analytics are unimportant themes or that the other mentioned themes have been entirely overlooked. Readers should keep in mind that these results are based on the answers of SCM researchers. Surveying researchers from other fields may have led to a different set of conclusions (e.g., ITrelated researchers with more knowledge may have emphasized big data more). 


\section{REFERENCES}

Amaral, J. and Tsay, A.A. 2009. “How to Win 'Spend’ and Influence Partners: Lessons in Behavioral Operations from the Outsourcing Game.” Production and Operations Management 18 (6):621-634.

Bode, C. and Wagner, S.M. 2015. “Structural Drivers of Upstream Supply Chain Complexity and the Frequency of Supply Chain Disruptions.” Journal of Operations Management 36:215-228.

Di Stefano, G., Gino, F., Pisano, G., and Staats, B. 2015. “Learning by Thinking: Overcoming the Bias for Action through Reflection.” Harvard Business School Working Paper Series No. 14-093, March 2014, revised March 2015.

Droge, C., Jayaram, J., and Vickery, S.K. 2004. “The Effects of Internal versus External Integration Practices on Time-Based Performance and Overall Firm Performance.” Journal of Operations Management 22 (6):557-573.

Durach, C.F., Wieland, A., and Machuca, J.A.D. 2015. “Antecedents and Dimensions of Supply Chain

Robustness: A Systematic Literature Review.” International Journal of Physical Distribution \& Logistics Management 45 (1/2):118-137.

Economist Intelligence Unit 2013. Global Manufacturing Outlook. Competitive Advantage: Enhancing Supply Chain Networks for Efficiency and Innovation. London, UK.

Flynn, B.F., Huo, B., and Zhao, X. 2010. “The Impact of Supply Chain Integration on Performance: A Contingency and Configuration Approach.” Journal of Operations Management 28 (1):58-71.

Handfield, R., Straube, F., Pfohl, H.-C., and Wieland, A. 2013. Trends and Strategies in Logistics and Supply Chain Management: Embracing Global Logistics Complexity to Drive Market Advantage, Hamburg, Germany: BVL.

Kersten, W., von See, B., and Skirde, H. 2014. "Identification of Megatrends Affecting Complexity in Logistics Systems.” In Next Generation Supply Chains: Trends and Opportunities, edited by Kersten, W., Blecker, T., and Ringle, C.M., 3-27.

Kouvelis, P., Chambers, C., and Wang, H. 2006. “Supply Chain Management Research and Production and Operations Management: Review, Trends, and Opportunities.” Production and Operations Management 15 (3):449-469.

Lawrence, F. 2013. “Horsemeat Scandal: The Essential Guide.” The Guardian February 15.

Melnyk, S.A., Lummus, R.R., Vokurka, R.J., Burns, L.J., and Sandor, J. 2009. "Mapping the Future of Supply Chain Management: A Delphi Study.” International Journal of Production Research 47 (16):4629-4653.

Meyer, M.A. and Booker, J.M., 1991. Eliciting and Analyzing Expert Judgement: A Practical Guide 7, Academic Press. 
Mudambi, R., 2008. “Location, Control and Innovation in Knowledge-intensive Industries.” Journal of Economic Geography 8 (5):699-725.

PETA 2014. A Look Inside the Angora Rabbit Wool Industry.

https://secure.peta.org/site/Advocacy?id=5171

Pettit, T.J., Fiksel, J. and Croxton, K.L. 2010. “Ensuring Supply Chain Resilience: Development of a Conceptual Framework.” Journal of Business Logistics 31 (1):1-21.

Sanders, N.R., Zacharia, Z.G., and Fugate, B.S. 2013. “The Interdisciplinary Future of Supply Chain Management Research.” Decision Sciences 44 (3):413-429.

Stank, T.P., Dittmann, J.P., and Autry, C.W. 2011. “The New Supply Chain Agenda: A Synopsis and Directions for Future Research.” International Journal of Physical Distribution \& Logistics Management 41 (10):940-955.

Tangpong, C., Hung, K.-T., and Li, J. 2014. “Agent-System Co-Development in Supply Chain Research: Propositions and Demonstrative Findings.” Journal of Operations Management 32 (4):154-174.

The Global Supply Chain Institute 2013. Game-Changing Trends in Supply Chain: First Annual Report by the Supply Chain Management Faculty at the University of Tennessee, Knoxville, TN.

Vallet-Bellmunt, T., Martínez-Fernández, M.T., and Capó-Vicedo, J. 2011. “Supply Chain Management: A Multidisciplinary Content Analysis of Vertical Relations Between Companies, 1997-2006.” Industrial Marketing Management 40 (8):1347-1367.

Waller, M.A. and Fawcett, S.E. 2013. "Data Science, Predictive Analytics, and Big Data: A Revolution that Will Transform Supply Chain Design and Management.” Journal of Business Logistics 34 (2):77-84. Wieland, A. and Handfield, R. 2013. “The Socially Responsible Supply Chain: An Imperative for Global Corporations.” Supply Chain Management Review 17 (5):22-29. 
Table 1: Scholars' perceptions of underestimated and overestimated emerging research themes in the next five years.

\begin{tabular}{|c|c|c|}
\hline Rank & Research Theme & Difference \\
\hline 1 & People Dimension of SCM & 0.65 \\
\hline 2 & Ethical Issues & 0.63 \\
\hline 3 & Integration (Internally between Departments) & 0.44 \\
\hline 4 & Transparency/Visibility & 0.39 \\
\hline 5 & Human Capital / Talent Management & 0.39 \\
\hline 6 & Co-opetition & 0.30 \\
\hline 7 & Humanitarian Issues & 0.30 \\
\hline 8 & Reverse Logistics & 0.29 \\
\hline 9 & Behavioral Issues & 0.27 \\
\hline 10 & City Logistics & 0.25 \\
\hline 11 & Complexity & 0.24 \\
\hline 12 & Volatility/Turbulence & 0.23 \\
\hline 13 & Sustainability (Ecological, Economic, Ethical, Social) & 0.22 \\
\hline 14 & Disaster Relief / Emergency Management & 0.22 \\
\hline 15 & Innovation & 0.20 \\
\hline 16 & Resilience & 0.18 \\
\hline 17 & Environmental/Green Issues & 0.18 \\
\hline 18 & Disruption & 0.17 \\
\hline 19 & Coordination & 0.12 \\
\hline 20 & Integration (Externally between Firms) & 0.10 \\
\hline 21 & International/Global Issues & 0.10 \\
\hline 22 & Multi-tier Management & 0.09 \\
\hline 23 & Health Care & 0.09 \\
\hline 24 & Real-time Information & 0.08 \\
\hline 25 & Networks & 0.06 \\
\hline 26 & Backsourcing/In-sourcing & 0.05 \\
\hline 27 & Servitization/Services & 0.03 \\
\hline 28 & Finance & 0.03 \\
\hline 29 & Risk Management & 0.03 \\
\hline 30 & Emerging Markets & 0.02 \\
\hline 31 & Information Security & -0.03 \\
\hline 32 & Re-shoring/Backshoring & -0.04 \\
\hline 33 & IT/Digitalization & -0.08 \\
\hline 34 & Analytics & -0.34 \\
\hline 35 & Big Data & -0.69 \\
\hline
\end{tabular}

Note: The "difference" score was calculated as the difference between the shouldbecome-important score and the will-become-important score. A positive [negative] score indicates an underestimated [overestimated] research theme. 
Table 2: Some future research potentials when recombining the research themes.

\begin{tabular}{|c|c|c|c|c|c|}
\hline & Sustainability & Risk Management & $\begin{array}{c}\text { People and } \\
\text { Behavior }\end{array}$ & Innovation & Analytics \\
\hline $\begin{array}{r}\text { Risk } \\
\text { Management }\end{array}$ & \begin{tabular}{|l} 
Including the \\
broader context \\
into SCM (e.g. \\
laws, trends). \\
- Considering social \\
and ecological \\
issues as \\
reputational risks. \\
Including \\
sustainability in \\
supply chain risk \\
models.
\end{tabular} & & & & \\
\hline $\begin{array}{l}\text { People and } \\
\text { Behavior }\end{array}$ & $\begin{array}{l}\text { Managing } \\
\text { perceptions of } \\
\text { sustainability in } \\
\text { the supply chain. } \\
\text { - Influencing culture } \\
\text { to increase } \\
\text { sustainability in } \\
\text { supply chains. } \\
\text { Closing the } \\
\text { attitude-behavior } \\
\text { gap of } \\
\text { sustainability. }\end{array}$ & $\begin{array}{l}\text { Managing risk } \\
\text { preferences and } \\
\text { risk perceptions. } \\
\text { Managing biases } \\
\text { and heuristics in } \\
\text { risk identification. } \\
\text { Optimizing the } \\
\text { supply chain } \\
\text { structure to } \\
\text { manage risk. }\end{array}$ & & & \\
\hline Innovation & $\begin{array}{l}\text { Exploring/exploiti } \\
\text { ng SCM potential } \\
\text { of sustainable } \\
\text { products. } \\
\text { Using smart } \\
\text { technologies to } \\
\text { create } \\
\text { sustainability. } \\
\text { Relationship } \\
\text { between } \\
\text { innovative and } \\
\text { sustainable firms. }\end{array}$ & $\begin{array}{l}\text { Linking disruptive } \\
\text { innovations and } \\
\text { supply chain risk. } \\
\text { Reducing product } \\
\text { recalls for } \\
\text { innovative } \\
\text { products. } \\
\text { Using the Internet } \\
\text { of Things to } \\
\text { reduce risk in the } \\
\text { network design. }\end{array}$ & $\begin{array}{l}\text { Dealing with } \\
\text { resistance to } \\
\text { supply chain } \\
\text { innovations. } \\
\text { Managing } \\
\text { irrational decision } \\
\text { making in the } \\
\text { innovation } \\
\text { process. } \\
\text { Investigating } \\
\text { culture of inter- } \\
\text { organizational } \\
\text { innovation. }\end{array}$ & & \\
\hline Analytics & $\begin{array}{l}\text { Driving metrics to } \\
\text { create end-to-end } \\
\text { visibility. } \\
\text { Measuring social/ } \\
\text { ecological } \\
\text { footprint along } \\
\text { supply chain. } \\
\text { Predicting impact } \\
\text { of real-time events } \\
\text { on } \mathrm{CO}_{2} \text { footprint. }\end{array}$ & $\begin{array}{ll}\text { Improving early- } \\
\text { warning systems. } \\
\text { Providing } \\
\text { advanced risk } \\
\text { metrics. } \\
\text { Analyzing and } \\
\text { predicting impact } \\
\text { of decisions on } \\
\text { supply chain } \\
\text { resilience. }\end{array}$ & $\begin{array}{ll}\text { - Improving } \\
\text { decision-support } \\
\text { tools in SCM. } \\
\text { Enabling better } \\
\text { interpretation of } \\
\text { SCM information. } \\
\text { - Involving social } \\
\text { media data in } \\
\text { SCM analytics } \\
\text { tools. }\end{array}$ & 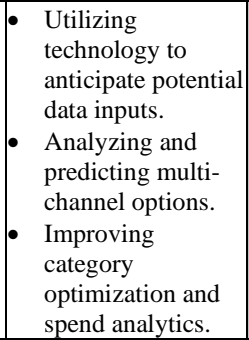 & \\
\hline Complexity & $\begin{array}{ll}\text { - } & \text { Redesigning } \\
\text { supply chains to } \\
\text { improve } \\
\text { sustainability. } \\
\text { - } \\
\text { Reducing waste } \\
\text { by managing } \\
\text { supply chain } \\
\text { complexity. } \\
\text { - Investigating } \\
\text { impact of } \\
\text { complexity on } \\
\text { sustainability } \\
\text { initiatives. }\end{array}$ & 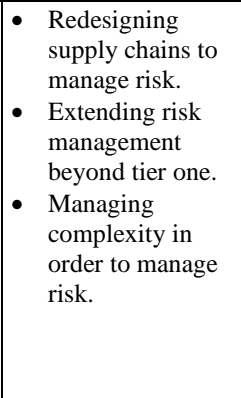 & $\begin{array}{l}\text { Accepting that } \\
\text { SCM decisions } \\
\text { are inherently } \\
\text { imperfect. } \\
\text { - Handling } \\
\text { complexity when } \\
\text { making joint } \\
\text { SCM decisions. } \\
\text { Managing talents } \\
\text { to better deal } \\
\text { with complex } \\
\text { situations. }\end{array}$ & $\begin{array}{ll}\text { - } & \text { Managing } \\
\text { innovation } \\
\text { projects with } \\
\text { complex supply } \\
\text { chain } \\
\text { interactions. } \\
\text { - Using } \\
\text { technologies to } \\
\text { reduce network } \\
\text { complexity. } \\
\text { Investigating } \\
\text { "Manufacturing } \\
\text { 4.0" }\end{array}$ & $\begin{array}{l}\text { - Making sense of } \\
\text { the "sea of data" } \\
\text { along the supply } \\
\text { chain. } \\
\text { - Supporting real- } \\
\text { time supply } \\
\text { chain decision } \\
\text { making. } \\
\text { - Enabling true } \\
\text { end-to-end } \\
\text { supply chain } \\
\text { integration. }\end{array}$ \\
\hline
\end{tabular}

Note: A similar but empty table was sent to 13 SCM researchers and used as an instrument to collect the data. 